\title{
Two Distinct EF-Tu Epitopes Induce Immune Responses in Rice and Arabidopsis
}

\author{
Takehito Furukawa, Hiroaki Inagaki, Ryota Takai, Hiroyuki Hirai, and Fang-Sik Che \\ Graduate School of Bio-Science, Nagahama Institute of Bio-Science and Technology, 1266, Tamura, Nagahama, Shiga 526- \\ 0829, Japan
}

Submitted 9 October 2013. Accepted 28 October 2013.

\begin{abstract}
Plants sense potential pathogens by recognizing conserved pathogen-associated molecular patterns (PAMPs) that cause PAMP-triggered immunity (PTI). We previously reported that rice recognizes flagellin from the rice-incompatible N1141 strain of Acidovorax avenae and subsequently induces immune responses. Cell extracts isolated from flagellin-deficient N1141 ( $\Delta$ fla1141) still induced PTI responses, suggesting that $\Delta$ fla1141 possesses an additional PAMP distinct from flagellin. Here, we show that elongation factor Tu (EF-Tu), one of the most abundant bacterial proteins, acts as a PAMP in rice and causes several PTI responses. In Brassicaceae species, EF-Tu and an $\mathrm{N}$-acetylated peptide comprising the first 18 amino acids of the N-terminus, termed elf18, are fully active as inducers of PTI responses. By contrast, elf18 did not cause any immune responses in rice, whereas an EF-Tu middle region comprising Lys176 to Gly225, termed EFa50, is fully active as a PAMP in rice. In the leaves of rice plants, EF-Tu induced $\mathrm{H}_{2} \mathrm{O}_{2}$ generation and callose deposition, and also triggered resistance to coinfection with pathogenic bacteria. Taken together, these data demonstrate that rice recognizes EFa50, which is distinct from elf18, and that this epitope induces PTI responses.
\end{abstract}

Plants are continuously confronted with a variety of microorganisms, including potential pathogens. However, plants are resistant to most microbes and rely entirely on their own immune responses for their defense. Plants have evolved a multilayered defense system that can be activated upon pathogen invasion (Jones and Dangl 2006). The first layer includes pattern recognition receptors (PRR) that detect conserved microbial molecules, referred to as pathogen-associated molecular patterns (PAMPs) or microbe-associated molecular patterns. These molecules initiate PAMP-triggered immunity (PTI), which includes the generation of reactive oxygen species (the oxidative burst), callose deposition, and expression of several immune-related genes (Boller and Felix 2009). In addition, this first layer also includes the perception of host-derived "danger" signals (damage-associated molecular patterns) such as plant peptides or cell-wall fragments released during infection or wounding (Monaghan and Zipfel 2012). In the second layer of immunity, host resistance proteins recognize pathogen

Corresponding author: F. S. Che; E-mail: k_sai@nagahama-i-bio.ac.jp

* The $e$-Xtra logo stands for "electronic extra" and indicates that two supplementary figures are published online.

(C) 2014 The American Phytopathological Society effector molecules, triggering a rapid defense response that often includes a localized programmed cell death reaction known as the hypersensitive response (HR) (Coll et al. 2011).

PAMPs include characteristic structures from pathogens such as $\beta$-glucan (Klarzynski et al. 2000), polysaccharide chitin (Kaku et al. 2006), ergosterol (Laquitaine et al. 2006), lipopolysaccharide (LPS) (Silipo et al. 2005), flagellin (Che et al. 2000; Felix et al. 1999), and the translation elongation factor (EF)-Tu (Kunze et al. 2004). Among these PAMPs, flagellin, the main component of the bacterial flagellum, has been the most extensively studied in regard to its recognition mechanism and signal transduction. Arabidopsis recognizes the most conserved N-terminal domain of flagellin, which consists of a 22-amino-acid peptide (flg22) (Felix et al. 1999). Recognition of this active domain depends on FLS2 (flagellin sensing 2), which is a receptor-like kinase (RLK) composed of an extracellular leucine-rich repeat (LRR) domain, a single membranespanning domain, and a cytoplasmic serine/threonine kinase domain (Gómez-Gómez and Boller 2000). FLS2 and flg22 physically interact, suggesting that FLS2 determines specific recognition of flagellin.

EF-Tu, one of the most abundant bacterial proteins, also acts as a very potent bacterial PAMP in Arabidopsis and other Brassicaceae species (Kunze et al. 2004). As with flg22 and flagellin, Arabidopsis plants specifically recognize an $\mathrm{N}$-acetylated peptide comprising the N-terminal 18 amino acids of EF-Tu, termed elf18, and induce immune responses upon exposure to this peptide. By contrast, the shorter peptide elf12, comprising the acetyl group and the first $12 \mathrm{~N}$-terminal amino acids, is inactive as a PAMP but acts as a specific antagonist of elf18 (Kunze et al. 2004). Although EF-Tu is mostly intracellular, its release from lysis of dying bacteria during plant colonization is sufficient to trigger its recognition (Zipfel et al. 2006).

$\mathrm{EF}-\mathrm{Tu}$ is recognized by the elongation factor $\mathrm{Tu}$ receptor (EFR), a Brassicaceae-specific PRR (Zipfel et al. 2006). EFR is very similar to FLS2 and also belongs to the RLK family LRR-RK XII. The EFR structure contains a 21-LRR extracellular domain, a transmembrane domain, and a cytoplasmic Ser/Thr kinase domain (Boller and Felix 2009). Responsiveness to elf18 has been reported in various Brassicaceae species but not in members of other plant families, indicating that perception of EF-Tu as a PAMP is an innovation in Brassicaceae (Kunze et al. 2004; Zipfel et al. 2006). This restricted perception of EF-Tu may be due to the fact that no orthologs of EFR exist in other plant families. In fact, no EFR orthologs have been reported in rice, even though numerous genes encoding LRR-RKs of very similar architectures are contained in the rice genome (Boller and Felix 2009). Notably in this regard, transient expression of the EFR gene in Nicotiana benthami$a n a$, a plant lacking an endogenous EF-Tu perception system, 
conferred elf 18 responsiveness to this species, indicating that the downstream elements of PRR activation are conserved between Arabidopsis and other plant species (Lacombe et al. 2010).

Acidovorax avenae is a gram-negative bacterium that causes a seedling disease characterized by the deposition of brown stripes on the sheaths of infected plants. A. avenae has a wide host range among monocotyledonous plants; however, individual strains of this pathogen infect only one or a few host species (Kadota et al. 1996). For example, strains isolated from rice such as $\mathrm{K} 1$ can infect only rice plants (virulent), whereas the N1141 strain isolated from finger millet cannot infect rice (avirulent). We reported that the rice-avirulent N1141 strain of A. avenae induces several immune responses, such as HR cell death, $\mathrm{H}_{2} \mathrm{O}_{2}$ generation, and the upregulation of immunerelated genes, whereas the rice-virulent $\mathrm{K} 1$ strain of $A$. avenae does not induce these immune responses (Che et al. 1999; Fujiwara et al. 2004; Iwano et al. 2002; Tanaka et al. 2001, 2003). To identify the specific recognition molecules related to the induction of these immune responses in cultured rice cells, a strain-specific antibody was raised against the avirulent strain and then incubated with the virulent strain. The specific antibody detected the flagellin protein, which is structurally different between virulent and avirulent strains of $A$. avenae (Che et al. 2000). Flagellin purified from the avirulent N1141 strain induced rice immune responses, whereas flagellin purified from the virulent $\mathrm{K} 1$ strain did not induce these responses. Recombinant K1 and N1141 flagellins generated by an Escherichia coli expression system induced equally strong PTI responses, suggesting that post-translational modifications of the flagellins are involved in the specific induction of immune responses. Structural and immune-induction analysis using glycosyltransferase-deficient mutants revealed that the glycans at Ser178 and Ser183 in K1 flagellin prevent epitope recognition in rice (Hirai et al. 2011).

The purified N1141 flagellin also induced the expression of several immune-related genes, including $P A L, C h t-1$, and $P B Z 1$. A flagellin-deficient derivative of N1141 ( $\Delta$ fla1141), however, still induced $P A L, C h t-1$, and $P B Z 1$ expression, suggesting that $\triangle$ fla1141 possesses additional factors, distinct from flagellin, that act as inducers of PTI in rice (Tanaka et al. 2003). Here, we show that EF-Tu from A. avenae N1141 acts as a PAMP in rice plants and causes several PTI responses, including $\mathrm{H}_{2} \mathrm{O}_{2}$ generation, callose deposition, and induction of several immune-related genes. We localized the epitope recognized as a PAMP by rice to the middle region of EF-Tu. By contrast, synthesized elf18 did not induce any PTI responses in rice, although the peptide was able to induce Arabidopsis immune responses, suggesting that the EF-Tu recognition system in rice is different from that in Arabidopsis.

\section{RESULTS}

\section{Crude bacterial cell extracts from a flagellin-deficient N1141 strain ( $\Delta$ fla1141) contain PAMPs distinct from flagellin.}

The generation of $\mathrm{H}_{2} \mathrm{O}_{2}$ is one of the most characteristic events among the earliest immune responses in plant cells treated with bacterial preparations and, therefore, can serve as a convenient, rapid, sensitive, and quantitative bioassay for studies of PAMP perception (Schwacke and Hager 1992). We first examined whether $\mathrm{H}_{2} \mathrm{O}_{2}$ generation is induced by cell extract (CE) from a flagellin-deficient derivative of the N1141 strain, $\Delta$ fla1141. When $C E$ from $\Delta$ fla1141 was added to cultured rice cells, $\mathrm{H}_{2} \mathrm{O}_{2}$ was generated within 90 min after treatment, and the rate of $\mathrm{H}_{2} \mathrm{O}_{2}$ generation gradually decreased until $3 \mathrm{~h}$ after treatment (Fig. 1A). This induction activity was com- pletely abolished when the $\mathrm{CE}$ was boiled in $6 \mathrm{M} \mathrm{HCl}$ or digested with trypsin (Fig. 1A).

Callose deposition is another well-studied component of plant PTI responses (Luna et al. 2011). Therefore, we tested whether CE from $\Delta$ fla1141 causes callose deposition. When rice leaves were treated with $\mathrm{CE}$ and stained with aniline blue $16 \mathrm{~h}$ after treatment to visualize callose, more abundant callose deposition was observed in CE-treated rice leaves than in water-treated rice leaves (Fig. 1B and C).

Previously, we have reported that expression levels of OsWRKY70, which encodes flagellin-inducible transcription factor (Takai et al. 2007); OsCht-I, which encodes chitinase (Tanaka et al. 2003); and OsEDS1, which encodes a factor related to immune signaling, are increased upon the addition of purified N1141 flagellin (Fujiwara et al. 2004), whereas OsNAC4, which encodes a key transcription factor involved in HR cell death, is not induced by flagellin treatment (Kaneda et al. 2009). To determine whether CE from $\Delta$ fla1141 can affect the expression levels of these genes in cultured rice cells, we performed quantitative real-time reverse-transcriptase polymerase chain reaction (RT-PCR). OsWRKY7O and OsEDS1 transcripts were induced $1 \mathrm{~h}$ after treatment with $\mathrm{CE}$, and gradually reduced until $6 \mathrm{~h}$ after treatment (Fig. 1D). OsCht-1 transcript was also observed $1 \mathrm{~h}$ after treatment, and its expression level gradually increased up to $6 \mathrm{~h}$ after treatment. By contrast, the level of OsNAC4 mRNA did not increase within $6 \mathrm{~h}$ after $\mathrm{CE}$ treatment (Fig. 1D). These results, together with the data regarding $\mathrm{H}_{2} \mathrm{O}_{2}$ generation and callose deposition described above, indicate that additional proteinaceous factors that can induce rice PTI responses are present in $\Delta$ fla1141.

\section{Purification and identification}

of the proteinaceous PTI inducing factor from $\Delta$ fla1141.

As the first step of purification, crude bacterial extract was isolated from $\Delta$ fla1141 and fractionated on a Q sepharose column. The main activity eluted with $300 \mathrm{mM} \mathrm{NaCl}$ (Fig. 2A), and proteins in fractions with PAMP activity were pooled. After concentration and desalinization using ultrafiltration, proteins were separated by two-dimensional (2D) gel electrophoresis, in which the first dimension was on $\mathrm{pH}$ gradient strips of $\mathrm{pH} 3$ to 10 and the second dimension was sodium dodecyl sulfatepolyacrylamide gel electrophoresis (SDS-PAGE). Proteins were detected by silver staining. We detected nine proteins in the SDS-PAGE separation (Fig. 2B), and these proteins were excised from the gel. Subsequently, the proteins were digested with trypsin, the generated peptides were analyzed by matrixassociated laser desorption ionization time-of-flight mass spectrometry (MALDI-TOF-MS), and peptide fragment spectra were obtained by liquid chromatography (LC) MS/MS. Peptide mass fingerprints and peptide sequence information were used to search for protein identity in databases. Spots 1 and 2 were identified as isochorismatase hydrolase and CSISPR-associated protein, respectively. Three spots (3, 4, and 8) were matched with the same protein, type I glutamine synthetase. Spots 5 and 6 matched with the same hypothetical protein. Proteins present in spots 7 and 9 could be identified as EF-Tu and $\delta$-aminolevulinic acid dehydratase, respectively (Fig. 2C).

\section{Identification of the $\boldsymbol{E F}$-Tu gene in A. avenae N1141.}

Among the proteins identified as PAMP candidates from CE of $\Delta$ fla1141, only EF-Tu has been reported as a PAMP that induces PTI responses in Arabidopsis and Brassicaceae species (Kunze et al. 2004; Zipfel et al. 2006). Therefore, we first attempted to determine whether EF-Tu from A. avenae N1141 can act as a PAMP in rice. To determine the DNA sequence of $E F-T u$ in $A$. avenae N1141, we searched for $E F-T u$ genes in the whole-genome sequence of $A$. avenae subsp. citrulli, a 
close relative of $A$. avenae N1141, because we have not yet obtained a whole-genome sequence of the A. avenae N1141 strain. We identified two EF-Tu genes in A. avenae subsp. citrulli, and designed and synthesized two sets of specific oligonucleotide primers based on these genes. PCR amplification from genomic DNA of A. avenae N1141 produced identically sized products of 1,191 bp from both primer pairs. Nucleotide sequence analysis of these two PCR products revealed that the two genes shared high sequence identity $(99.66 \%$ at the nucleotide level) but were localized in different parts of the genome (Supplementary Fig. S1A). Thus, the two genes were designated EF-Tu-al and EF-Tu-a2. The deduced amino-acid se-
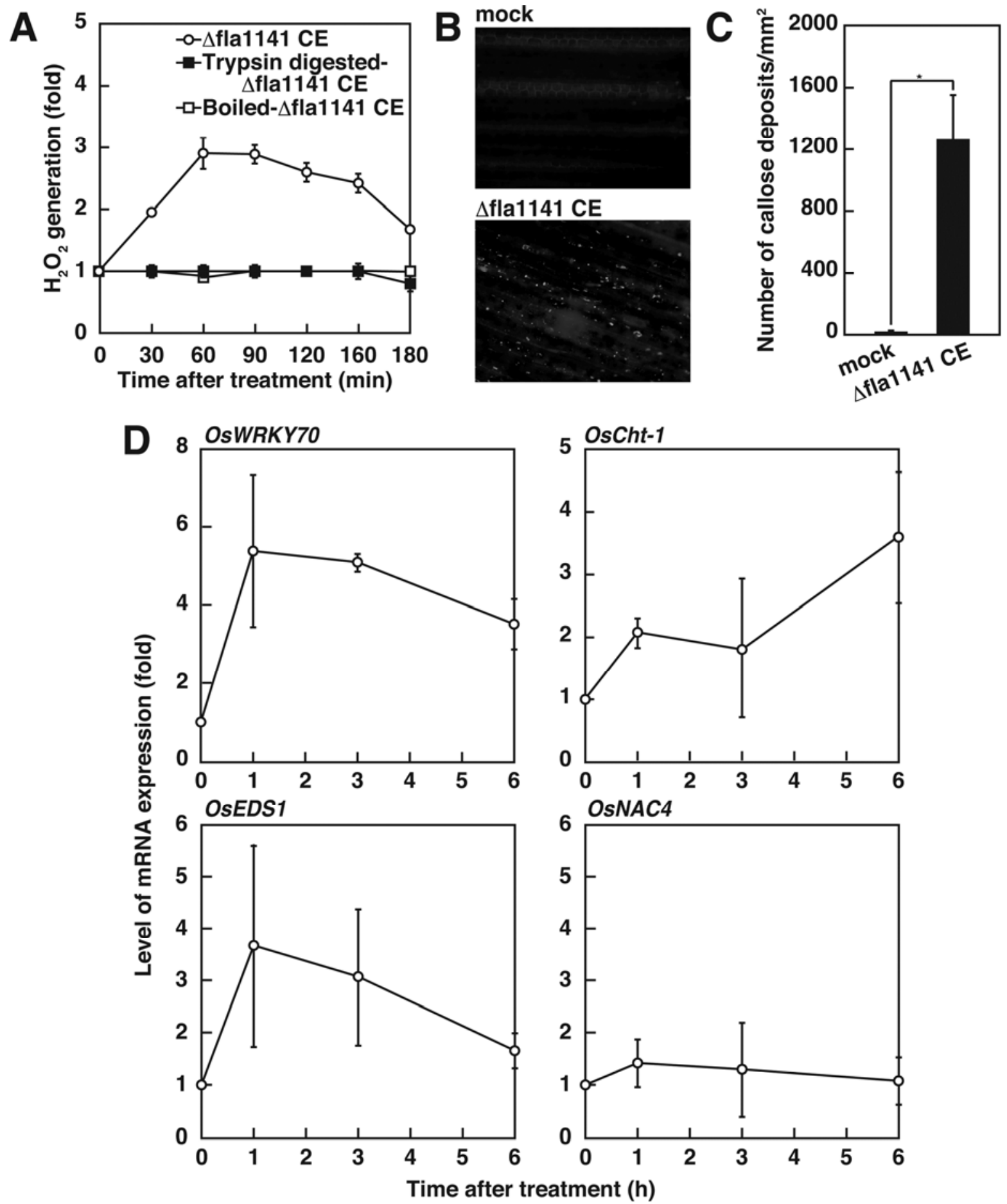

Fig. 1. Induction of immune responses in rice by cell extract (CE) from $\Delta$ fla1141. A, Time course of $\mathrm{H}_{2} \mathrm{O}_{2}$ generation in cultured rice cells treated with CE at $10 \mu \mathrm{g} / \mathrm{ml}$ from $\Delta$ fla1141 (open circles), trypsin-digested CE at $10 \mu \mathrm{g} / \mathrm{ml}$ from $\Delta$ fla1141 (solid squares), or CE at $10 \mu \mathrm{g} / \mathrm{ml}$ from $\Delta$ fla1141 boiled at $110^{\circ} \mathrm{C}$ with $6 \mathrm{~N} \mathrm{HCl}$ (open squares). The $y$ axis represents fold change relative to amount of $\mathrm{H}_{2} \mathrm{O}_{2}$ in cultured cells before treatment. Bars indicate the standard deviation of the mean of three experiments. B, Callose deposition in wild-type 'Nipponbare' leaves treated with CE at $10 \mu \mathrm{g} / \mathrm{ml}$ from $\Delta$ fla1141 (lower) or mocktreated (upper). C, Average numbers of callose deposits per 1- $\mathrm{mm}^{2}$ microscopic field. Bars indicate the standard deviation of nine experiments. Asterisk (*) indicates a significant increase $(t$ test, $P<0.01$ ) in the number of callose deposits in cells treated with CE from $\Delta$ fla1141. D, OsWRKY70, OsCht-1, OsEDS1, and OsNAC4 mRNA levels in cultured rice cells that were treated with CE at $10 \mu \mathrm{g} / \mathrm{ml}$ from $\Delta$ fla1141. mRNA levels were calculated from the threshold point located in the log-linear range of reverse-transcriptase polymerase chain reaction. The $y$ axis represents the fold change in mRNA levels relative to the levels in cultured cells before treatment. Error bars indicate the standard deviation of three experiments. 
quences of EF-Tu-al and EF-Tu-a2 indicated that EF-Tu-a1 and EF-Tu-a2 of A. avenae N1141 are each composed of 396 amino acids and that their amino-acid sequences are identical. Because both EF-Tu-al and EF-Tu-a2 produce identical proteins, we decided to use EF-Tu-al, hereafter designated EF$\mathrm{Tu}-\mathrm{a}$, for subsequent experiments.

To determine whether the EF-Tu-a is primarily responsible for PTI responses in rice cells, we expressed GST-tagged EFTu-a in E. coli and removed the GST moiety using PreScission protease. The MALDI-TOF-MS spectrum of the purified recombinant EF-Tu-a showed that the recombinant EF-Tu-a had a molecular mass of 43,448 Da, very close to the calculated molecular mass, suggesting that the recombinant EF$\mathrm{Tu}-\mathrm{a}$ is not post-translationally modified. To investigate the PAMP activity of recombinant EF-Tu-a, we examined $\mathrm{H}_{2} \mathrm{O}_{2}$ generation as a readout for PTI responses, using a 5-amino2,3 dihydro-1,4-phthalazinedione (luminol)-chemiluminescence assay (Schwacke and Hager 1992). EF-Tu-a was added to cultured rice cells and $\mathrm{H}_{2} \mathrm{O}_{2}$ generation was observed after treatment. The maximal generation of $\mathrm{H}_{2} \mathrm{O}_{2}$ was observed at $600 \mathrm{nM}$ EF-Tu-a, and the half-maximal effective concentration $\left(\mathrm{EC}_{50}\right)$ was estimated at $300 \mathrm{nM}$ (Fig. 3A).

When the rice leaves were treated with $300 \mathrm{nM}$ recombinant EF-Tu-a and stained with aniline blue $16 \mathrm{~h}$ later in order to visualize callose, abundant callose deposition was observed (Fig. 3B). We next investigated the effects of the recombinant EF-Tua on the expression of several immune-related genes. To this end, we added $300 \mathrm{nM}$ recombinant EF-Tu-a to cultured rice cells and extracted total RNA after $0,1,3$, and $6 \mathrm{~h}$. OsWRKY70 was most abundant $1 \mathrm{~h}$ after treatment, and gradually reduced until $6 \mathrm{~h}$ after treatment (Fig. 3C). Accumulation of OsCht-1 mRNA was also observed $1 \mathrm{~h}$ after treatment, and the expression level gradually increased up to $6 \mathrm{~h}$ (Fig. 3C). OsEDS1 mRNA was also induced by treatment with recombinant EF-Tu-a, and maximum accumulation was observed $3 \mathrm{~h}$ after treatment (Fig. $3 \mathrm{C})$. By contrast, no accumulation of OsNAC4 mRNA was detected within $6 \mathrm{~h}$ after treatment with recombinant EF-Tu-a (Fig. 3C). The patterns of several immune responses induced by recombinant EF-Tu-a were almost the same as those induced by CE from $\Delta$ fla1141, consistent with the idea that PAMP activity in $\mathrm{CE}$ was derived from EF-Tu-a and suggesting that EF-Tu-a acts as a very potent PAMP in rice.

\section{Identification of the PAMP-active epitope of EF-Tu-a.}

In Arabidopsis, the elf18 peptide corresponding to the conserved $18 \mathrm{~N}$-terminal residues of EF-Tu is recognized by EFR, which belongs to the RLK family. Because no EFR orthologs exist in rice, it is predicted that elf 18 does not act as a PAMP in this species (Boller and Felix 2009). To explore the mechanism of EF-Tu perception in rice, we first examined the effect of the elf18 region of A. avenae EF-Tu-a on PAMP activity. An amino-acid sequence corresponding to elf18 is also found in the N-terminal region (residues 2 to 19) of N1141 EF-Tu-a, although the sequences differ by two amino acids (Fig. 4A). To compare these peptides, we chemically synthesized both elf 18 and elf18-avenae, which corresponds to the elf18 position of
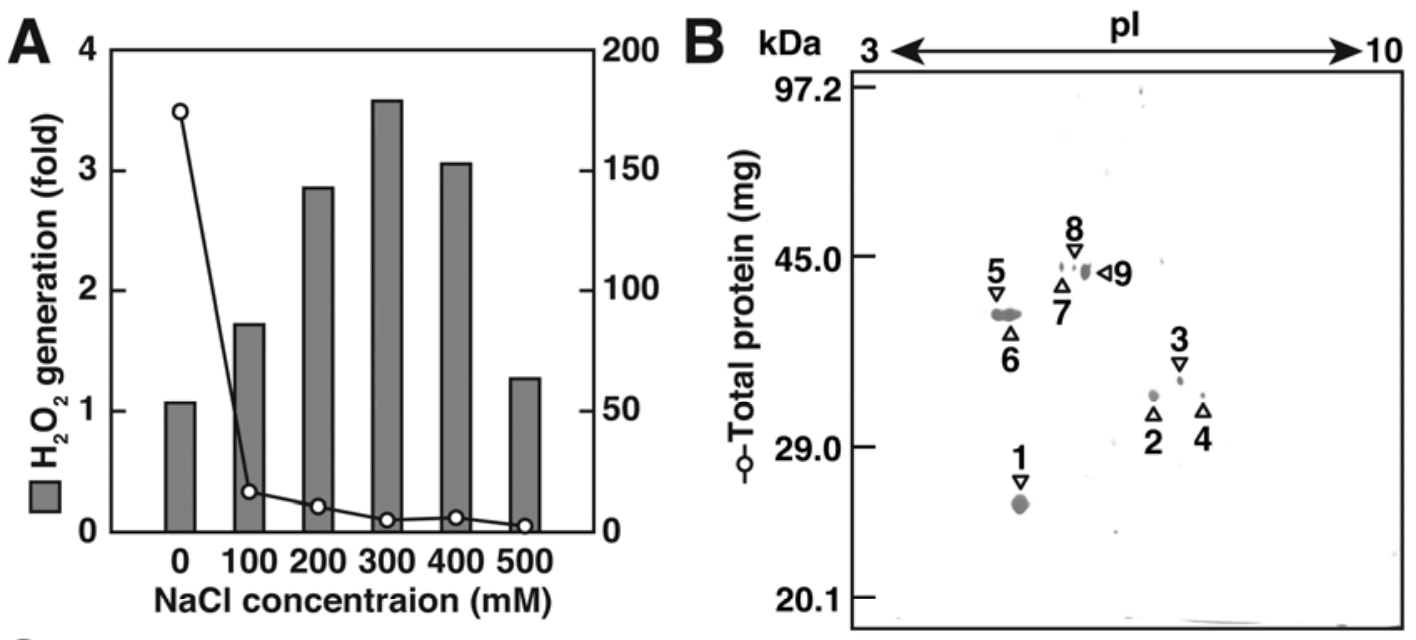

\begin{tabular}{|c|c|c|}
\hline Spot No. & Identified protein & NCBI accession No. \\
\hline 1 & Isochorismatase hydrolase & gi|120611492 \\
\hline 2 & CRISPR-associated protein, Csd 2 family & gi|270494315 \\
\hline 3 & Glutamine synthetase, type I & gi|270491639 \\
\hline 4 & Glutamine synthetase, type I & gi|270491639 \\
\hline 5 & Hypothetical protein AcavDRAFT_3545 & gi|270494756 \\
\hline 6 & Hypothetical protein AcavDRAFT 3545 & gi 270494756 \\
\hline 7 & Translation elongation factor $\mathrm{Tu}$ & gi|270496056 \\
\hline 8 & Glutamine synthetase, type I & gi|270491639 \\
\hline 9 & $\delta$-aminolevulinic acid dehydratase & gi|270493504 \\
\hline
\end{tabular}

Fig. 2. Isolation of pathogen-associated molecular pattern active protein from cell extract $(\mathrm{CE})$ of $\Delta$ fla1141. A, $\mathrm{H}_{2} \mathrm{O}_{2}$ generation in cultured rice cells that were treated with $5 \mu \mathrm{g} / \mathrm{ml}$ eluates from Q Sepharose anion exchange chromatography (gray bars). The $y$ axes on the left represent the fold change relative to the amount of $\mathrm{H}_{2} \mathrm{O}_{2}$ in cultured cells before treatment. Open circles indicate the amounts of total protein in each fraction. B, Silver-stained two-dimensional gel electrophoresis image of the fraction that eluted at $300 \mathrm{mM} \mathrm{NaCl}$. Numbers shown on the left represent the molecular mass in kilodaltons. $\mathbf{C}$, Spot numbers refer to spots identified. 
A. avenae N1141 EF-Tu. To determine the immune-induction activity of these peptides, we measured $\mathrm{H}_{2} \mathrm{O}_{2}$ generation in rice and Arabidopsis cells treated with elf 18 and elf18-avenae. Neither elf18 nor elf18-avenae induced $\mathrm{H}_{2} \mathrm{O}_{2}$ generation in cultured rice cells but both peptides stimulated $\mathrm{H}_{2} \mathrm{O}_{2}$ generation in Arabidopsis suspension cells (Fig. 4B). These results suggest that the elf18 region of A. avenae N1141 does not induce PTI responses in rice, even though this peptide functions as a PAMP in Arabidopsis.

Because immune responses in rice were not induced by the elf18 region of EF-Tu-a, we next investigated the exact epitope sites of N1141 EF-Tu-a in rice. To determine the exact epitope
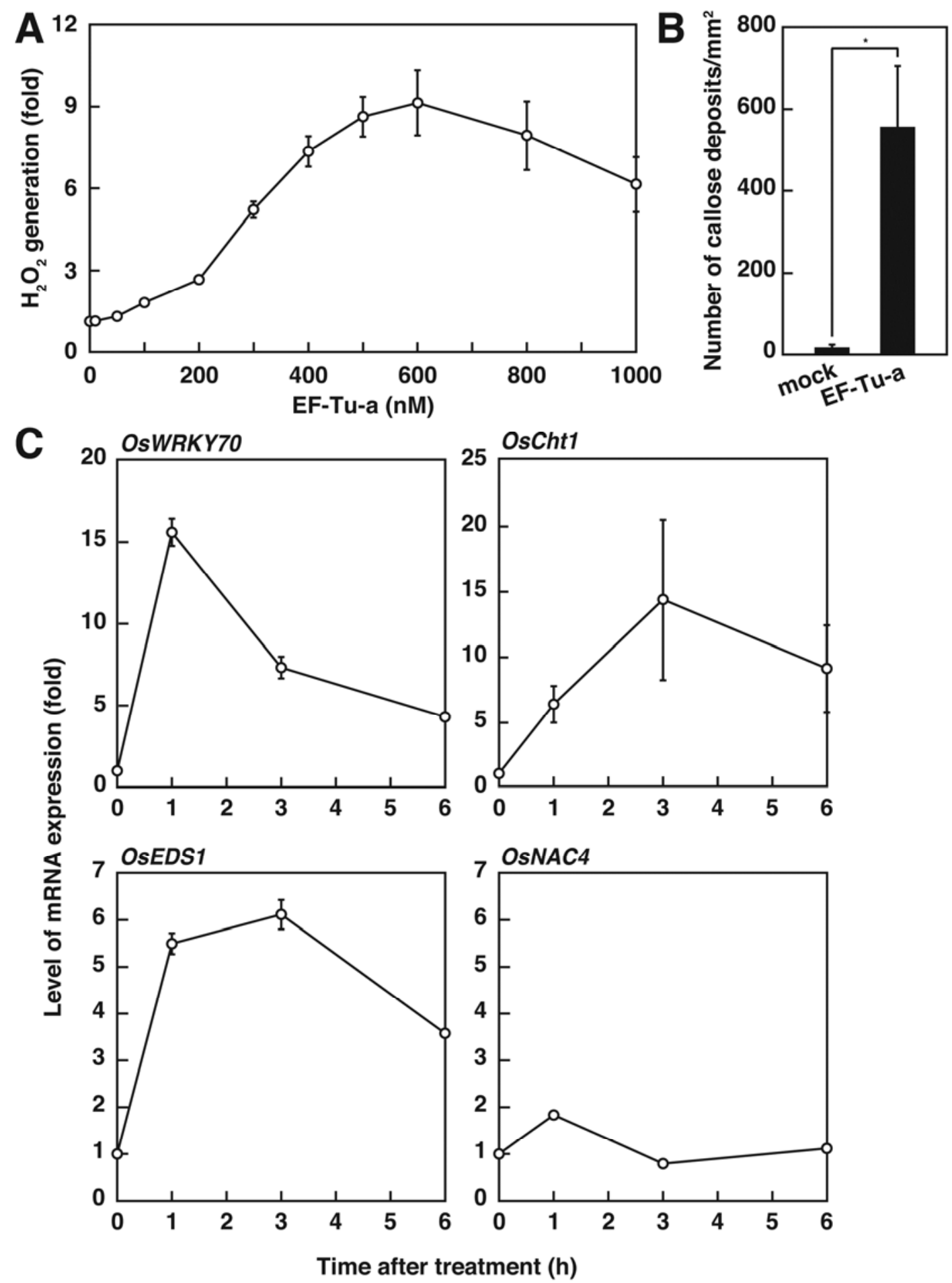

Fig. 3. Induction of immune responses in rice by elongation factor (EF)-Tu-a. $\mathbf{A}, \mathrm{H}_{2} \mathrm{O}_{2}$ generation in cultured rice cells treated with EF-Tu-a. Different doses of recombinant EF-Tu-a were assayed for their effect on $\mathrm{H}_{2} \mathrm{O}_{2}$ generation in cultured rice cells 90 min after EF-Tu-a treatment. The $y$ axis represents the fold change in $\mathrm{H}_{2} \mathrm{O}_{2}$ in treated cell cultures relative to the levels in cultured cells before treatment. Error bars indicate the standard deviation of four experiments. B, Callose deposition in wild-type 'Nipponbare' leaves treated with $300 \mathrm{nM}$ EF-Tu-a. The $y$ axis represents the average numbers of callose deposits per 1 -mm ${ }^{2}$ microscopic field. Error bars indicate the standard deviation of nine experiments. Asterisk (*) indicates a significant increase $(t$ test, $P<0.01)$ in the number of callose deposits in cells treated with EF-Tu-a. C, OsWRKY70, OsCht-1, OsEDS1, and OsNAC4 mRNA levels in cultured rice cells treated with 300 nM EF-Tu-a. mRNA levels were calculated from the threshold point located in the log-linear range of reverse-transcriptase polymerase chain reaction. The $y$ axis represents the fold change in mRNA levels relative to the levels in cultured cells before treatment. Error bars indicate the standard deviation of three experiments. 
site in rice, we produced three fragments of EF-Tu-a (EF-Tu-a 1-200, EF-Tu-a 101-300, and EF-Tu-a 201-396) as GST fusion proteins in E. coli and removed the GST portion of each fusion protein using PreScission protease (Fig. 5A). Cultured rice cells treated with the EF-Tu-a 101-300 produced higher levels of $\mathrm{H}_{2} \mathrm{O}_{2} 90$ min after treatment than cells treated with EF-Tu-a, whereas no induction of $\mathrm{H}_{2} \mathrm{O}_{2}$ generation was observed when cells were treated with EF-Tu-a 1-200 or EF-Tu-a 201-396 (Fig. 5B).

Because EF-Tu-a 101-300 functioned as s PAMP in rice, we produced six deletion peptides of EF-Tu-a 101-300: EF-Tu-a 151-250, EF-Tu-a 176-225, EF-Tu-a 181-220, EF-Tu-a 186215, EF-Tu-a 176-205, and EF-Tu-a 196-225 (Fig. 5A). EFTu-a 151-250 caused $\mathrm{H}_{2} \mathrm{O}_{2}$ generation in cultured rice cells 90 min after treatment. This induction activity was also present in a shorter deletion protein, EF-Tu-a 176-225, whereas other deletion proteins, including EF-Tu-a 181-220, EF-Tu-a 186-215, EF-Tu-a 176-205, and EF-Tu-a 196-225, did not induce $\mathrm{H}_{2} \mathrm{O}_{2}$ generation (Fig. 5B). These results indicate that the epitope site recognized by rice is contained within EF-Tu-a 176-225. We termed this peptide $\mathrm{EFa} 50$, in reference to the middle 50 amino acids of EF-Tu from $A$. avenae N1141. To confirm the specific immune induction of EFa50, Arabidopsis suspension cells were treated with EF-Tu-a or other deletion proteins, including $\mathrm{EFa} 50$, and $\mathrm{H}_{2} \mathrm{O}_{2}$ generation was measured. The treatment of EF-Tu-a 201-396, EF-Tu-a 101-300, or EF-Tu-a 176225 (EFa50) did not induced $\mathrm{H}_{2} \mathrm{O}_{2}$ generation, whereas EF-Tua and EF-Tu-a 1-200 that included the elf18 region caused induction of $\mathrm{H}_{2} \mathrm{O}_{2}$ generation in Arabidopsis cells (Fig. 5C).

The dose-response experiment using EF-Tu-a 101-300, which includes the $\mathrm{EFa} 50$ epitope but not elf18 region, showed that the $\mathrm{EC}_{50}$ in rice cells was estimated at $50 \mathrm{nM}$, which is lower than that of EF-Tu-a (Fig. 6A). We also investigated whether EFa50 also induced other PTI responses in rice such as callose deposition and induction of several immune-related genes, as in the case of full-length EF-Tu-a. When rice leaves were treated with $300 \mathrm{nM}$ elf18 and EF-Tu-a 101-300, clear callose deposition was observed only in EFa50-treated leaves (Fig. 6B). Next, we examined induction of OsWRKY70 gene expression by EFa50 using quantitative real-time RT-PCR. In- duction of $O s W R K Y 70$ mRNA expression was observed $1 \mathrm{~h}$ after treatment with $300 \mathrm{nM}$ EF-Tu-a 101-300, whereas no induction was observed in elf18-treated cultured rice cells (Fig. 6C). Expression of OsChtl was also induced by treatment with EF-Tu-a 101-300, and the maximal induction was observed after $3 \mathrm{~h}$ after treatment (Fig. 6C). OsEDS1 mRNA expression was also induced $1 \mathrm{~h}$ after EF-Tu-a 101-300 treatment. By contrast, elf18 did not significantly induce remarkable $O s C h t 1$ or OsEDS1 mRNA expression (Fig. 6C). In summary, these results demonstrate that rice cells have a sensitive perception system specifically recognizing the middle domain of EF-Tu, and that a minimal peptide comprising amino acids 176 to 225 of EF-Tu appears to be required for full activity as a PAMP in rice.

\section{Genome-wide identification of genes regulated by the EF-Tu recognition signal.}

To obtain an overview of the role of EF-Tu-a in PTI responses in rice, we generated transcriptome profiles (Agilent Technologies 44K rice DNA Oligo Microarray) from cultured rice cells exposed to EF-Tu-a 101-300. Cultured rice cells were treated with $300 \mathrm{nM}$ EF-Tu-a 101-300 for $0,1,3$, or $6 \mathrm{~h}$, and mRNAs from the treated cells were used as probes for microarray analysis. After quantitation of the signal intensities and normalization, we identified 5,451 genes that exhibited upor downregulation during EF-Tu-a 101-300 treatment (using a cutoff of a fourfold difference in transcript levels between treated and nontreated cells). To gain insight into the mechanisms of immunity induced by EF-Tu-a, we performed hierarchical clustering analysis of these 5,451 genes. These genes could be classified into six clusters (A to F). Clusters A, B, and $\mathrm{C}$ contained genes that were downregulated after EF-Tu-a 101-300 treatment (2,065 genes in total), whereas clusters D, $\mathrm{E}$, and $\mathrm{F}$ contained genes that were upregulated after the treatment. Among the upregulated gene clusters, gene cluster D consisted of 618 genes whose expression was strongly increased by EF-Tu-a 101-300 treatment, gene cluster E consisted of 1,315 genes whose expression was gradually increased, and gene cluster $\mathrm{F}$ consisted of 1,433 genes with an early induction pattern. The upregulated clusters contained many previously
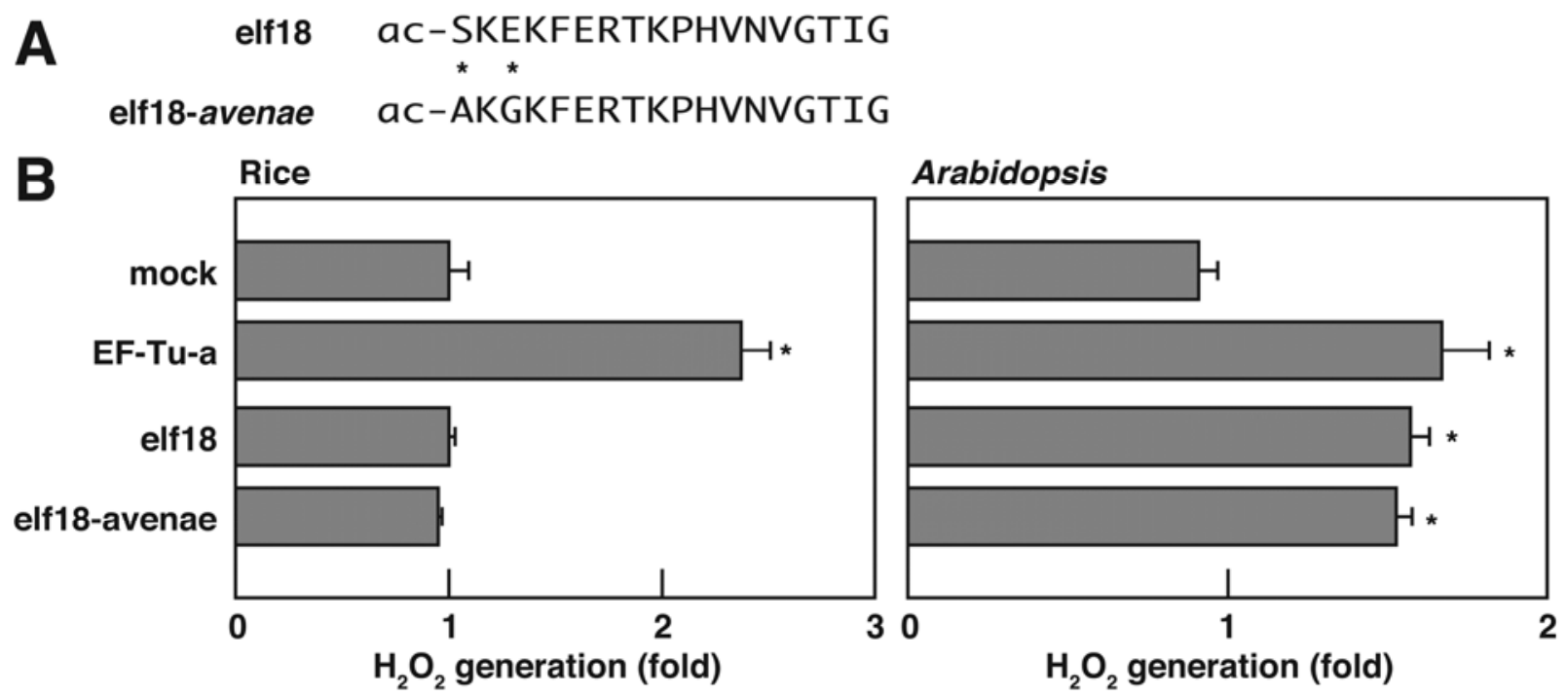

Fig. 4. Difference in induction of $\mathrm{H}_{2} \mathrm{O}_{2}$ generation by elf18 between rice and Arabidopsis. A, Amino acid sequences of elf18 and elf18 from elongation factor (EF)-Tu-a (elf18-avenae). Asterisks (*) indicate two amino-acid differences between elf 18 and elf 18 -avenae. $\mathbf{B}$, $\mathrm{H}_{2} \mathrm{O}_{2}$ generation in cultured rice (left panel) or Arabidopsis (right panel) cells treated with $300 \mathrm{nM}$ EF-Tu-a, elf18, and elf18-avenae. EF-Tu-a, elf18, and elf18-avenae were assayed for $\mathrm{H}_{2} \mathrm{O}_{2}$ generation 30 or 90 min after treatment in Arabidopsis suspension cells and cultured rice cells, respectively. The $x$ axis represents the fold change in $\mathrm{H}_{2} \mathrm{O}_{2}$ in treated cell cultures relative to the levels in cultured cells before treatment. Error bars indicate the standard deviation of three experiments. Asterisks (*) indicate a significant increase $(t$ test, $P<0.01)$ in the amount of $\mathrm{H}_{2} \mathrm{O}_{2}$ induced by EF-Tu-a, elf18, and elf18-avenae in cultured cells. 
reported PTI-related genes (Fujiwara et al. 2004) and each cluster contained similar types of PTI-related genes. For example, cluster $\mathrm{F}$ contained genes encoding transcription factors and signal transduction factors such as WRKY transcription factor 1, WRKY transcription factor 70, a zinc-finger transcription factor, a RING-type domain containing protein, EFhand $\mathrm{Ca}^{2+}$-binding protein CCD1, EL2 protein, and a DUF family protein. Cluster $\mathrm{E}$ contained genes encoding pathogenicity-related (PR) proteins and phytoalexin biosynthesis enzymes such as PR-1a, probenazole-inducible protein PBZ1, endochitinase, thaumatin, and phenylalanine ammonia lyase. By contrast, no effector-triggered immunity (ETI)-related genes such as OsNAC4 were included in the upregulated gene clusters, suggesting that EF-Tu-a 101-300 induces the PTI response rather than the ETI response.

\section{Induction of resistance.}

Pretreatment of Arabidopsis leaves with elf18 triggers the induction of disease resistance and restricts growth of the pathogenic bacterium Pseudomonas syringae pv. tomato DC3000 (Zipfel et al. 2006). Therefore, we next examined whether EFTu-a induces a similar effect when co-injected into leaves with A. avenae avirulent $\mathrm{N} 1141$ and virulent K1 strains. The number of N1141 cells increased slightly up until 1 day after inoculation but decreased 3 and 5 days after inoculation. When N1141 was co-injected with EF-Tu-a, a significant 30-fold reduction of N1141 growth was observed 5 days after inoculation (Fig. 7A). By contrast, EF-Tu-a did not induce this effect on growth of $A$. avenae $\mathrm{K} 1$ (Fig. 7B). Importantly, no direct effect of EF-Tu-a on bacterial growth could be detected in $A$. avenae $\mathrm{N} 1141$ or $\mathrm{K} 1$ growing in Luria-Bertani (LB) medium supplemented with $10 \mu \mathrm{M}$ EF-Tu-a, indicating that this peptide has no direct toxic effect (data not shown).

\section{DISCUSSION}

A. avenae is a devastating plant bacterial pathogen of staple monocotyledonous crops such as rice and corn. Our 2D-PAGE analysis revealed that EF-Tu of A. avenae N1141 is a candidate PAMP in rice. Several PTI responses, such as $\mathrm{H}_{2} \mathrm{O}_{2}$ generation and expression of PTI-related genes, were induced in cultured rice cells treated with recombinant EF-Tu-a protein, confirming that EF-Tu from $A$. avenae N1141 acts as a PAMP in rice. EF-Tu is a prokaryotic elongation factor involved in synthesis of new proteins by ribosomal translation. Specifically, EF-Tu binds aminoacyl transfer (t)RNAs and catalyzes the delivery of amino acids to nascent peptide chains on ribosomes in a GTP-dependent process. EF-Tu is one of the most abundant proteins in bacteria, and it constitutes as much as 5 to $10 \%$ of cytoplasmic protein in all bacteria investigated to date (Jonák 2007). The widely conserved domains of such abundant molecules often function as PAMPs. The protein flagellin, the building block of the motility organ called the flagellum (Samatey et al. 2001; Yonekura et al. 2003), is recognized by most plants and causes several immune responses. The main PAMP of flagellin in Arabidopsis is the conserved N-terminal domain, flg22 (Felix et al. 1999). The LPSs found in the outer membrane of gram-negative bacteria also cause several PTI responses in plants, and the main LPS PAMP is the widely conserved lipid A (Silipo et al. 2005). Similar to flagellin and LPS, a synthetic 18-amino-acid peptide based on the N-terminal conserved region of $E$. coli EF-Tu, elf18, is sufficient for recognition by Arabidopsis and other members of the Brassicaceae family (Kunze et al. 2004). Our results clearly showed that elf18-avenae did not induce any PTI responses in rice, even though EF-Tu-a acts as PAMP in rice. In addition, deletion analysis of EF-Tu indicated that the middle domain, com- prising amino acids 176 to 225 (EFa50), appears to be required for full PAMP activity in rice. These differing observations in Arabidopsis and rice suggest that Brassicaceae species recognize elf18 of EF-Tu, whereas PTI responses in rice are caused by the recognition of EFa50. Our findings should provide a key to understanding not only the mechanism of PTI induced by EF-Tu but also the evolution of the EF-Tu perception system.

As determined by X-ray analysis of available crystalline complexes of EF-Tu, the molecule consists of three domains: 1, 2, and 3 (Heffron et al. 2006). GDP/GTP binding and the GTPase active site of EF-Tu are situated in the N-terminal domain of the protein. Thus, domain 1 is also called the catalytic or G-domain. Domains 2 and 3 (noncatalytic domains) significantly but distinctively, depending on bacterial species, modulate the properties and activities of domain 1 (Jonák 2007). Therefore, the amino-acid sequence of domain 1 is highly conserved, whereas many substitutions of amino-acid residues are observed in domains 2 and 3. Although elf18 is contained

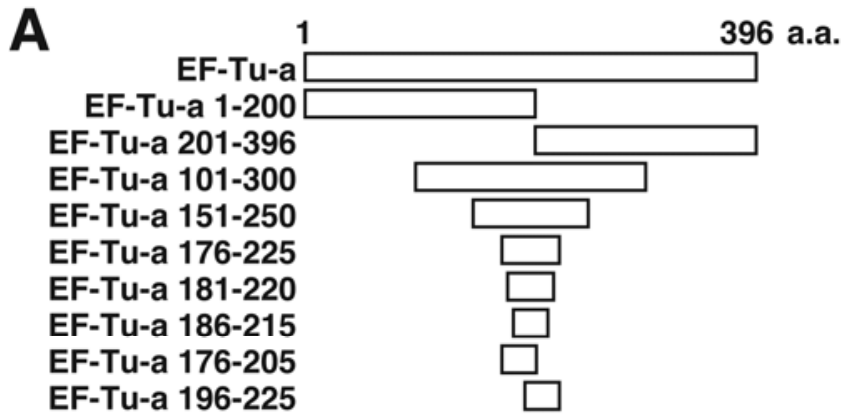

B

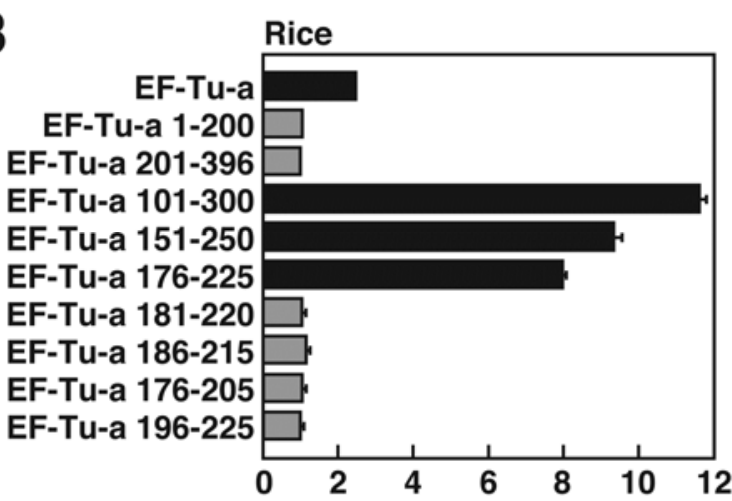

C

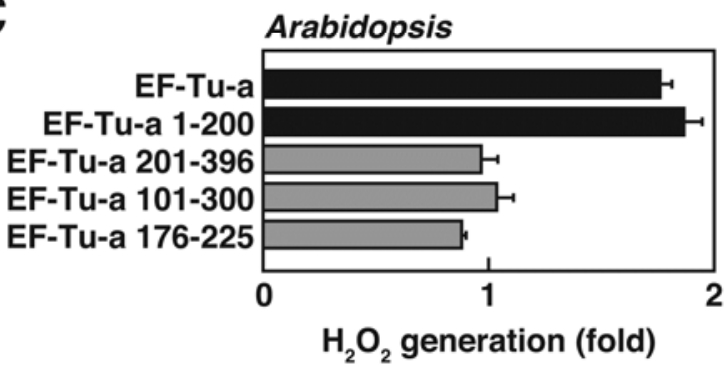

Fig. 5. $\mathrm{H}_{2} \mathrm{O}_{2}$ generation induced by elongation factor (EF)-Tu-a and EFTu-a peptides. A, EF-Tu-a and EF-Tu-a peptides. EF-Tu-a peptide names were derived from the amino-acid positions in the primary sequence of EF-Tu-a. B, $\mathrm{H}_{2} \mathrm{O}_{2}$ generation in cultured rice cells treated with $300 \mathrm{nM}$ EF-Tu-a and EF-Tu-a peptides, assayed 90 min after treatment. C, $\mathrm{H}_{2} \mathrm{O}_{2}$ generation in Arabidopsis suspension cells treated with $300 \mathrm{nM}$ EF-Tu-a and EF-Tu-a peptides, assayed $30 \mathrm{~min}$ after treatment. The $x$ axis represents the fold change in $\mathrm{H}_{2} \mathrm{O}_{2}$ in treated cell cultures relative to the levels in cultured cells before treatment. Black bars indicate a significant increase ( $t$ test, $P<0.01$ ) in the amount of $\mathrm{H}_{2} \mathrm{O}_{2}$ induced by EF-Tu-a and EF-Tu-a peptides in cultured cells. Error bars indicate the standard deviation of three experiments. 
within the conserved N-terminal domain 1, the epitope is composed of only four amino-acid residues. Use of only specific amino-acid residues within a conserved domain as a recognition site would facilitate recognition of EF-Tu derived from a wide range of bacterial species as a PAMP. By contrast, $\mathrm{EFa} 50$, which acts as a PAMP in rice, is contained within the joint region between domains 1 and 2, which are variable regions. In addition, the isoelectric point differs between elf18 (10.8) and EFa50 (3.9). Even though there are many differences between elf18 and EFa50 with respect to their aminoacid sequences or located region, elf 18 and $\mathrm{EFa} 50$ both cause several PTI responses, including $\mathrm{H}_{2} \mathrm{O}_{2}$ generation, callose deposition, and expression of PTI-related genes. Computer-assisted three-dimensional modeling of the EF-Tu protein predicts that at least the first $\mathrm{N}$-terminal 12 amino-acid residues of elf 18 are surface-exposed. EFa50 is also predicted to be located on the surface of the EF-Tu protein (Supplementary Fig. S2). The exposed surface of EFa50 seems to be important for recognition of EF-Tu with the EF-Tu receptor in rice.

In plants, PAMPs derived from several pathogenic bacteria are recognized by PRR, which are predominantly located on the plasma membrane but can also localize to endosomal com- partments or even the cytoplasm. The first identified and beststudied PRR is FLS2, the flagellin receptor in Arabidopsis. The primary sequence of FLS2 consists of a N-terminal signal peptide, 28 LRRs, a transmembrane domain, and a cytoplasmic kinase domain (Gómez-Gómez and Boller 2000). elf18 is also recognized by EFR, which belongs to LRR-TK subfamily XII. The structure of EFR is highly similar to that of FLS2, with a 21-LRR extracellular domain, a transmembrane domain, and a cytoplasmic Ser/Thr kinase domain (Zipfel et al. 2006). As in the case of FLS2, EFR is also phosphorylated (Schwessinger et al. 2011), suggesting that both FLS2 and EFR carry active kinase domains. EF-Tu responsiveness has been reported only in Brassicaceae species, suggesting that EFR is an innovation of this family. Rice, which has no EFR orthologs, activated several PTI responses by recognizing EFa50. The PTI responses induced by EFa50 were strongly inhibited by several protein kinase inhibitors such as staurosporine and K252a (unpublished data), indicating that protein phosphorylation is necessary for intracellular transduction of the EFa50 recognition signal. Although the receptor of EFa50 in rice remains unknown, it is likely that this receptor will be of the LRR-TK type, of which 300 or more examples exist in rice (Shiu et al. 2004). Because
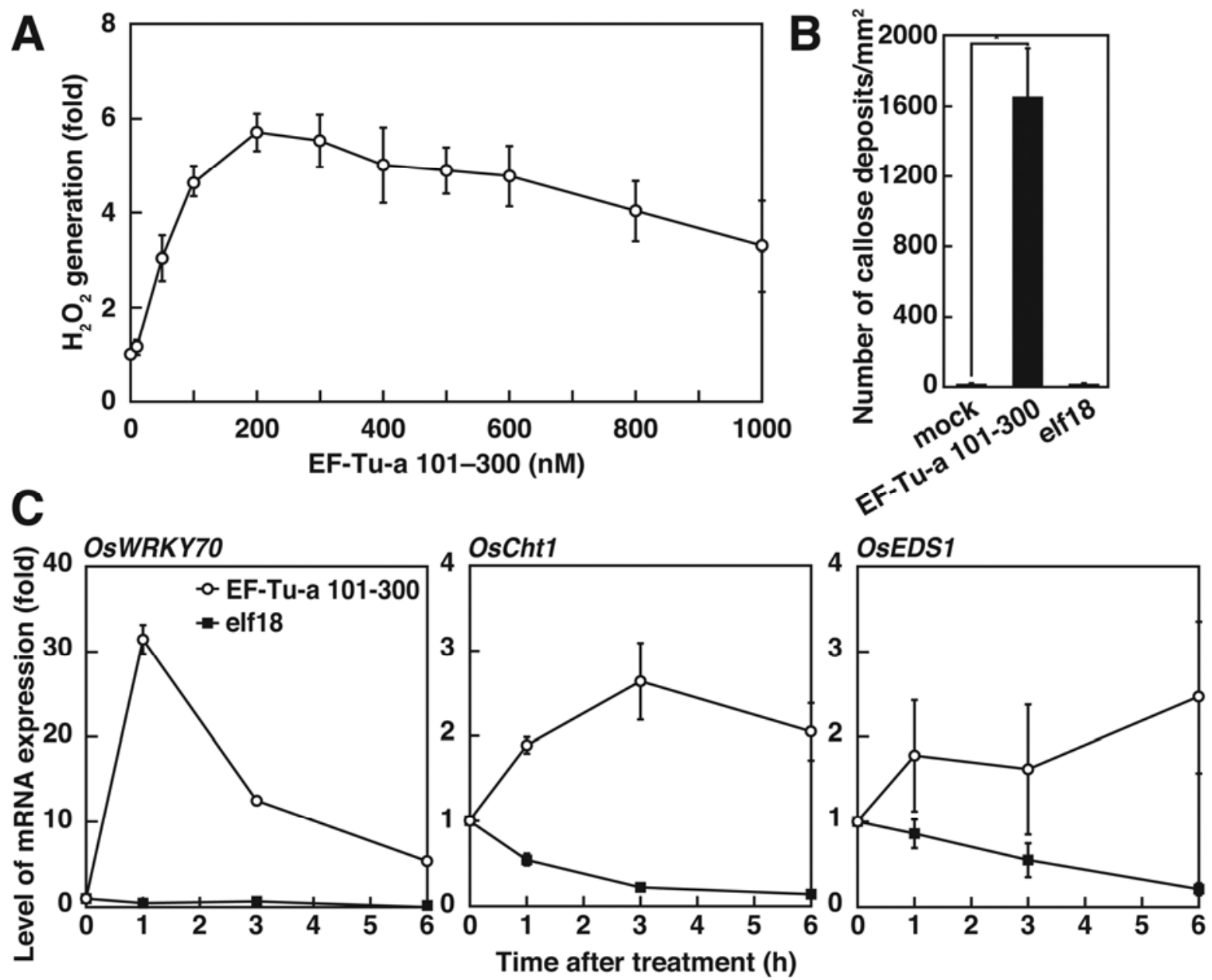

Fig. 6. Induction of immune responses in rice treated with elongation factor (EF)-Tu-a 101-300 and elf18. A, Dose-dependent $\mathrm{H}_{2} \mathrm{O}_{2}$ generation of EF-Tu-a 101-300. Different doses of recombinant EF-Tu-a 101-300 were added to cultured rice cells and amount of generated $\mathrm{H}_{2} \mathrm{O}_{2}$ was measured 90 min after EFTu-a 101-300 treatment. The $y$ axis represents the fold change in $\mathrm{H}_{2} \mathrm{O}_{2}$ in treated cell cultures relative to the levels in cultured cells before treatment. Error bars indicate the standard deviation of three experiments. B, Callose deposition in wild-type 'Nipponbare' leaves treated with 300 nM EF-Tu-a 101-300 or elf18. The $y$ axis represents average numbers of callose deposits per $1-\mathrm{mm}^{2}$ microscopic field. Error bars indicate the standard deviation of nine experiments. Asterisk (*) indicates a significant increase $(t$ test, $P<0.01)$ in the number of callose deposits in cells treated with EF-Tu-a 101-300. C, OsWRKY70, OsCht1, and OsEDS1 mRNA levels in cultured rice cells treated with $300 \mathrm{nM}$ EF-Tu-a 101-300 (open circles) or elf18 (solid squares). mRNA levels were calculated from the threshold point located in the log-linear range of reverse-transcriptase polymerase chain reaction. The $y$ axis represents the fold change in mRNA levels relative to the levels in culture cells before treatment. Error bars indicate the standard deviation of three experiments. 
EFR, which recognizes elf18 within EF-Tu, only exists in Brassicaceae species, the ability to recognize elf 18 must have been acquired after Brassicaceae species were evolutionarily established. Similarly, the ability to recognize EFa50 in rice also must have been acquired after rice evolutionarily diverged from the Brassicaceae family. Thus, the capability to recognize different parts of the same protein must be the result of convergent evolution in rice and Brassicaceae species. These findings also raise the possibility that different parts of EF-Tu, which is one of the most abundant and conserved bacterial proteins, are recognized by different receptor proteins in other plant species. Future study should examine in detail the abilities of multiple plant species to recognize EF-Tu.

Transient heterologous expression of AtEFR in N. benthami$a n a$, a plant that normally lacks elf18 responsiveness, restores elf18 binding and responses, demonstrating that downstream signaling components are conserved between members of the families Brassicaceae and Solanaceae (Lacombe et al. 2010). Furthermore, almost the same set of genes was induced by elf18 and flg22 in Arabidopsis, indicating that the downstream signaling events are shared between the responses to elf 18 and flg22, even though different receptors are involved (Zipfel et al. 2006). Our genome-wide expression profiling in this study revealed that genes upregulated in N1141 flagellin-treated cultured rice cells, as previously reported (Fujiwara et al. 2004; Takai et al. 2007; Tanaka et al. 2003), were also induced in cells treated with EF-Tu-a 101-300 (Fig. 8B). Furthermore, transient expression of AtEFR in protoplasts isolated from cultured rice cells also induced the elf18 response (unpublished data). These findings, together with our unpublished data, indicate that, in rice, the same signal transduction pathway lies downstream of EF-Tu recognition and flagellin recognition.

We previously reported that flagellin isolated from A. avenae N1141 causes several PTI responses, whereas flg22 induces no immune responses in cultured rice cells (Takai et al. 2008). However, overexpression of $O s F L S 2$, the rice ortholog of AtFLS2, causes the immune response to flg22, indicating that rice possesses a conserved FLS2-signaling pathway but that a receptor other than OsFLS2 is involved in recognition of flagellin in rice (Takai et al. 2008). BAK1 directly interacts with

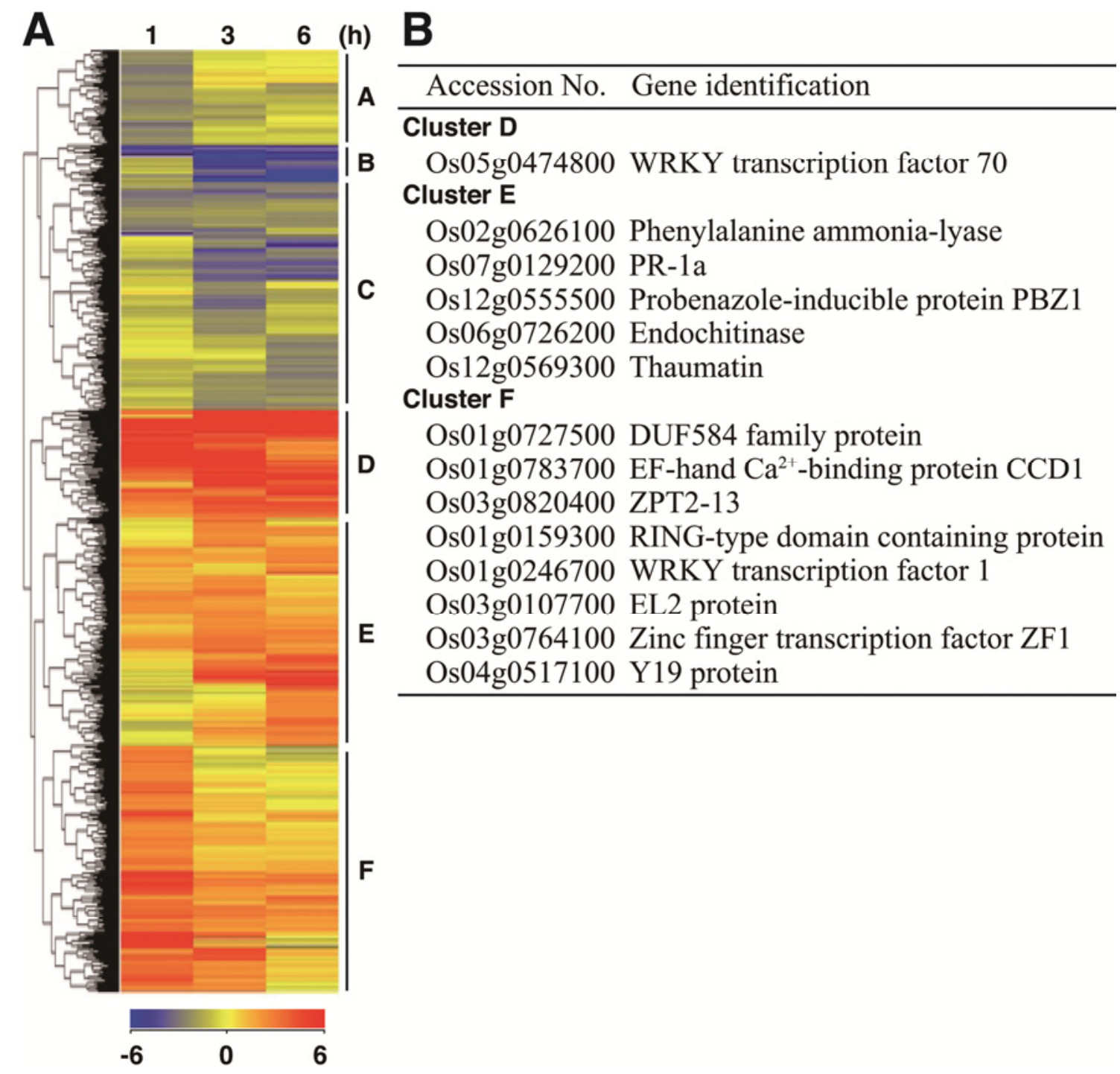

Fig. 7. Effect of elongation factor (EF)-Tu-a 101-300 on bacterial growth. A, Bacterial growth of rice-incompatible Acidovorax avenae strain N1141. Fourweek-old wild-type 'Nipponbare' rice plants were inoculated with A. avenae N1141 at $1 \times 10^{6}$ CFU with 300 pmol EF-Tu-a 101-300 (solid circles) or without EF-Tu-a 101-300 (open circles), and the bacterial population in the leaf was determined at the indicated times. The $y$ axis represents CFU per whole plant. Error bars indicate the standard deviation of three experiments. B, Bacterial growth of rice-compatible A. avenae strain K1. Four-week-old wild-type Nipponbare rice plants were inoculated by A. avenae K1 strain at $1 \times 10^{6} \mathrm{CFU}$ with 300 pmol EF-Tu-a 101-300 (solid squares) or without EF-Tu-a 101-300 (open squares), and the bacterial population in the leaf was determined at the indicated times. The $y$ axis represents CFU per whole plant. Error bars indicate the standard deviation of three experiments. 
FLS2 and EFR and acts as a positive PTI regulator for signaling events downstream of flg22 and elf18. Because the recognition signals of flagellin and EF-Tu were transformed into cells using a common signal transduction pathway, the unidentified flagellin receptor and EF-Tu receptor in rice must be regulated by a common factor such as BAK1. Identifying these receptors will also be essential to understanding the detailed molecular mechanisms of the resistance response induced by the flagellin and $\mathrm{EF}-\mathrm{Tu}$ in rice.

\section{MATERIALS AND METHODS}

\section{Plants and bacteria.}

Suspension cultures of rice cells (line Oc) were grown at $30^{\circ} \mathrm{C}$ under light irradiation. The cells were diluted in fresh medium every 7 days, and experiments were performed 4 days after transfer. Suspension cultures of Arabidopsis thaliana cells (line T87) were grown at $22^{\circ} \mathrm{C}$ under light irradiation. The cells were diluted in fresh medium every 7 days, and experiments were performed 7 days after transfer.

Acidovorax avenae N1141 (MAFF 301141) isolated from finger millet and strain K1 (MAFF 301755) isolated from rice were used as previously described (Che et al. 2000; Kadota et al. 1996).

\section{Preparation of cell extract \\ from the flagellin-deficient N1141 ( $\Delta$ fla1141) strain.}

Strain $\Delta$ fla1141 (Hirai et al. 2011) was grown in 4 liters of $\mathrm{LB}$ medium at $30^{\circ} \mathrm{C}$ for $16 \mathrm{~h}$ on a rotary shaker. The cells were harvested by centrifugation at $6,000 \times g$ for $20 \mathrm{~min}$ at $4^{\circ} \mathrm{C}$. The cell pellets were washed twice with $200 \mathrm{mM}$ potassium phosphate buffer ( $\mathrm{pH} \mathrm{7.0)}$ and resuspended in $120 \mathrm{ml}$ of the washing buffer. The resuspended bacterial cells were sonicated for $20 \mathrm{~min}$ at $4^{\circ} \mathrm{C}$ and then centrifugation at $10,000 \times g$ for $1 \mathrm{~h}$ to remove intact bacterial cells and other insoluble debris. The resulting supernatant was named CE from $\Delta$ fla 1141.

\section{$\mathrm{H}_{2} \mathrm{O}_{2}$ detection and quantification.}

$\mathrm{H}_{2} \mathrm{O}_{2}$ produced in the medium of cultured cells was monitored based on chemiluminescence due to the ferricyanidecatalyzed oxidation of luminol, as described by Schwacke and Hagar (1992). Cultured rice cells (10 mg) were transferred to $1 \mathrm{ml}$ of fresh medium and preincubated for $2 \mathrm{~h}$ at $30^{\circ} \mathrm{C}$. Cul- tured rice cells were incubated with $\mathrm{CE}$ from $\Delta$ fla 1141 at $30^{\circ} \mathrm{C}$ for variable periods after treatment. Following incubation, 10 liters of the medium were taken and mixed with 160 liters of $50 \mathrm{mM}$ potassium phosphate buffer $(\mathrm{pH} 7.9), 10$ liters of 1.1 $\mathrm{mM}$ luminol, and 20 liters of $14 \mathrm{mM}$ ferricyanide, and immediately analyzed for chemiluminescence with PHELIOS (ATTO, Tokyo).

\section{Callose deposition assay.}

Leaf disks (3-week-old japonica rice 'Nipponbare') were transferred to $1 \mathrm{ml}$ of fresh R2S medium and preincubated for $3 \mathrm{~h}$ at $30^{\circ} \mathrm{C}$. Leaf disks were incubated with CE from $\Delta$ fla 1141 at $30^{\circ} \mathrm{C}$ for $16 \mathrm{~h}$. After incubation, leaf disks were washed three times using $100 \mathrm{mM}$ potassium phosphate buffer $(\mathrm{pH} 8.0)$ and then fixed by Farmer's fixative at room temperature for $1 \mathrm{~h}$. After the fixation, leaf disks were washed three times with $100 \mathrm{mM}$ potassium phosphate buffer $(\mathrm{pH} \mathrm{8.0)}$ and then stained by $100 \mathrm{mM}$ potassium phosphate buffer $(\mathrm{pH} 8.0)$ containing $0.1 \%$ aniline blue for $4 \mathrm{~h}$. Leaf disks were washed three times with $100 \mathrm{mM}$ potassium phosphate buffer $(\mathrm{pH}$ 8.0) and callose deposition was visualized using a fluorescence microscope.

\section{Quantitative real-time RT-PCR.}

Total RNA was isolated from cultured rice cells using an RNeasy plant mini kit (Qigaen, Hilden, Germany) with DNase digestion according to the manufacturer's protocol. Quantitative real-time RT-PCR was performed on an Opticon2 instrument (Bio-Rad, Hercules, CA, U.S.A.) using a GoTaq OneStep RT-qPCR kit (Promega Corp., Madison, WI, U.S.A.) with WRKY70 gene-specific primers (forward, 5'-GGCGTCTCGTC CTCCGGGTT-3'; reverse, 5'-GTCGTAATCCAGCTGAACA A-3'), Cht-1 gene-specific primers (forward, 5'-TCTACACCT ACGACGCCTTC-3'; reverse, 5'-AGGAACGCGGCGACCTC GCGcg-3'), OsEDS1 gene-specific primers (forward, 5'-TTCC TCGCCTCCTTCGGCGC-3'; reverse, 5'-GAATGGCCTGTG AATACAAT-3'), and $O s N A C 4$ gene-specific primers (forward, 5'-AATCATCGCCGAGGTCGACC-3'; reverse, 5'-GGTCCCT CGGCGTGAAGAAG-3'). To eliminate DNA contamination during quantitative RT-PCR, the primer set was designed across an intron. The sizes of the PCR products were examined to confirm that only mRNA was amplified in all quantitative RTPCR experiments. The fluorescence data produced sigmoidal
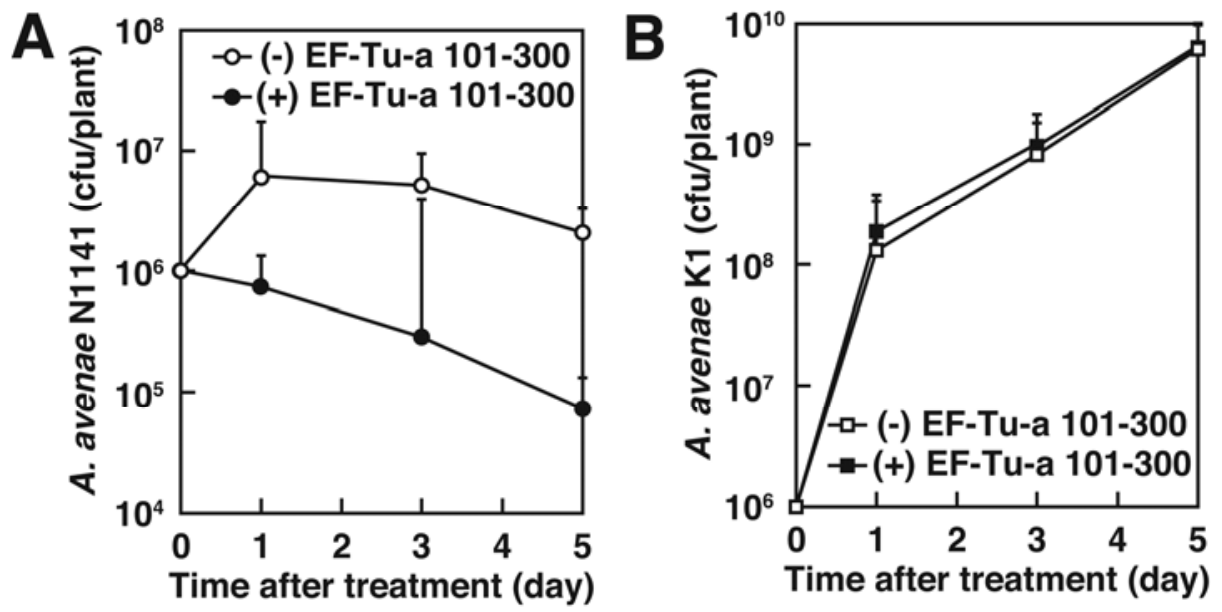

Fig. 8. Genome-wide expression profiling of transcriptional reprogramming triggered by elongation factor (EF)-Tu-a 101-300 treatment. A, Hierarchical clustering analysis of transcripts responsive to EF-Tu-a 101-300. Each column represent the fold change in transcript levels in EF-Tu-a 101-300-treated cultured rice cells at the indicated times, relative to the levels in cultured cells before treatment. The vertical dimension represents 5,451 genes that exhibit EFTu-a 101-300-triggered changes in transcript level (cutoff: $\mid \log _{2}$ [fold change] $\geq 2$ ). B, Flagellin-responsive genes contained in A. Genes that were upregulated by EF-Tu-a 101-300 treatment in cultured rice cells were divided into three clusters. Cluster D contains genes that were strongly upregulated. Cluster E contains genes whose levels gradually increased up to $6 \mathrm{~h}$. Cluster F contains genes whose levels declined until $6 \mathrm{~h}$ after treatment. 
amplification plots in which the number of cycles was plotted against the fluorescence. The WRKY70, Cht-1, OsEDS1, and OsNAC4 mRNA levels were normalized based on the reference gene Act-1.

\section{Identification of proteinaceour PAMP from CE from $\triangle$ fla1141.}

CE from $\Delta$ fla1141 was loaded onto anion exchange Q-Sepharose Fast Flow $(2.0$ by $10 \mathrm{~cm}$ ) (GE Healthcare, Milwaukee, WI, U.S.A.) equilibrated with $200 \mathrm{mM}$ potassium phosphate buffer ( $\mathrm{pH}$ 7.0). The column was washed two times using 200 $\mathrm{mM}$ potassium phosphate buffer ( $\mathrm{pH}$ 7.0) and PAMP activity was eluted with $200 \mathrm{mM}$ potassium phosphate buffer ( $\mathrm{pH} 7.0)$ containing $300 \mathrm{mM} \mathrm{NaCl}$. After desalinization of the active fraction by ultrafiltration, the sample $(800 \mu \mathrm{g}$ of total protein $)$ was separated by 2D-PAGE. The first-dimension separation was achieved using an Immobiline dry-strip gel ( $\mathrm{pH}$ range 3 to 10 ; length $=13 \mathrm{~cm})(\mathrm{GE}$ Healthcare $)$. The second-dimension separation was achieved by SDS-PAGE using original gels (separation distance $=16 \mathrm{~cm}$ ). The gel was silver stained without glutaraldehyde. Each spot was cut out and desilverized with desilverization solution containing $30 \mathrm{mM} \mathrm{K}{ }_{3}\left[\mathrm{Fe}(\mathrm{CN})_{6}\right]$ and $100 \mathrm{mM} \mathrm{Na} \mathrm{S}_{2} \mathrm{O}_{3}$ for $10 \mathrm{~min}$ at $25^{\circ} \mathrm{C}$. After removing the desilverization solution, the gel was washed with 500 liters of distilled water, and then dehydrated with 100 liters of $\mathrm{CH}_{3} \mathrm{CN}$. Each protein in the gel was digested in $50 \mathrm{mM} \mathrm{NH}_{4} \mathrm{HCO}_{3}$ and $2 \mathrm{mM} \mathrm{CH} \mathrm{CHOH}_{3} \mathrm{Containing}$ trypsin (modified sequencing grade) (Roche, Basel, Switzerland) for $16 \mathrm{~h}$ at $37^{\circ} \mathrm{C}$. The digested peptides were analyzed by liquid chromatography mass spectrometry ion trap TOF (Shimadzu, Kyoto, Japan).

\section{Cloning of $\mathrm{EF}-\mathrm{Tu}-\boldsymbol{a}$ and preparation of recombinant EF-Tu-a protein.}

To determine the DNA sequence of EF-Tu in A. avenae N1141, EF-Tu genes in the whole-genome sequence of $A$. avenae subsp. citrulli, a close relative of $A$. avenae N1141, were searched. Two sets of specific oligonucleotide primers were synthesized based on two EF-Tu genes in A. avenae subsp. citrulli (EF-Tu-al forward, 5'-TTGCAAAAGTTGCGCTTTC ACAAG-3'; reverse, 5'-CCCATGTGGCTCAGTGGTAGAG-3' and $E F-T u-a 2$ forward, 5'-AGTAAGTACCACCCCTGTGT-3'; reverse, 5'-GGATACGGATCTTTTGCTTGGA-3'). Two EFTu- $a$ genes of $A$. avenae N1141 were PCR amplified and sequence information was obtained by direct sequencing of the PCR products.

To prepare the GST-fused EF-Tu-a, the EF-Tu-al gene was PCR amplified using a specific primer set (forward, 5'-GGA TCCGCAAAAGGTAAGTTCGAACGTACC-3'; reverse, 5'-G TCGACTCAGGCAATGATCTTGGCCAC-3') from the A. avenae $\mathrm{N} 1141$ genome. $\mathrm{PCR}$ product was ligated and cloned into the pGEM-T vector (Promega Corp.). The resulting plasmid, EF-Tu-al/pGEM-T, was digested with SalI and BamHI and cloned into a pGEX-6p-3 vector (GE Healthcare); the resulting plasmid was termed $E F-T u$-al/pGEX-6p-3. GST-fused recombinant EF-Tu-a protein was expressed by isopropyl-thio-galactopyranoside treatment in BL21(DE3) carrying EF-Tu-al/ pGEX-6p-3 in LB medium at $37^{\circ} \mathrm{C}$ for $6 \mathrm{~h}$. The cells were harvested by centrifugation at $6,000 \times g$ for $20 \mathrm{~min}$ at $4^{\circ} \mathrm{C}$. The pellets were washed with $\mathrm{PBS}(\mathrm{pH} 7.3)$, then resuspended in $30 \mathrm{ml}$ of the same buffer. The resuspended bacterial cells were crushed by sonication for $5 \mathrm{~min}$ at $4^{\circ} \mathrm{C}$ and then centrifuged at $10,000 \times g$ to remove intact cells and cellular debris. The supernatant was applied to Gultathione Sepharose 4B (GE Healthcare) and eluted by PreScission Protease (GE Healthcare) according to the manufacturer's protocol. Concentrations of EF-Tu-a and EF-Tu-a fragments were determined by protein assay reagent (Thermo Scientific, Waltham, MA, U.S.A.) using bovine serum albumen as standard. For the control experiment, the same treatment and preparation were performed using BL21 (DE3) carrying pGEX-6p-3.

\section{Microarray analysis.}

Cultured rice cells were incubated with $\mathrm{R} 2 \mathrm{~S}$ medium containing $300 \mathrm{nM}$ EF-Tu-a $101-300$ at $30^{\circ} \mathrm{C}$ for various periods after treatment. Total RNA was isolated from cultured rice cells using the RNeasy plant mini kit (Qigaen) with DNase digestion according to the manufacturer's protocol. Microarray analysis was performed using the Rice Gene Expression Microarray kit, $4 \times 44 \mathrm{k}$ (Agilent Technologies, Santa Clara, CA, U.S.A.) at one color. cDNA probe labeling, hybridization, and scanning were performed according to the manufacturer's protocol. GeneSpring 12.6 (Agilent Technologies) was used for microarray data analysis.

\section{Inoculation test.}

For the inoculation of $A$. avenae, rice (Oryza sativa L. Nipponbare) was grown for 4 weeks in a natural-light phytotron at 30 and $25^{\circ} \mathrm{C}$ (day and night, respectively). One day before inoculation, the plants were placed in a growth chamber with a 16-h day $\left(200 \mu \mathrm{E} \mathrm{m}^{-2} \mathrm{~s}^{-1}\right.$ at $\left.30^{\circ} \mathrm{C}\right)$ and 8 -h night $\left(25^{\circ} \mathrm{C}\right)$ cycle and $65 \%$ relative humidity. The bacteria were suspended in sterilized distilled water $\left(2 \times 10^{9} \mathrm{CFU} / \mathrm{ml}\right)$ and then added with the same volume of distilled water containing each peptide. A $1-\mu 1$ $\left(10^{6} \mathrm{CFU}\right)$ drop of the bacterial suspension medium was formed on the end of a needle and then the sheath was pricked at a point $3 \mathrm{~cm}$ above the soil level. Control plants were mock inoculated with sterilized water. Inoculated seedlings were maintained in a growth chamber under the same conditions. The growth of K1 and N1141 strains was assessed in inoculated plants up to 5 days after inoculation. Four sets of randomly selected rice plants were harvested, rinsed thoroughly in sterile water, and homogenized in $10 \mathrm{mM} \mathrm{MgSO}_{4}$. Dilutions of the homogenate were plated onto Pseudomonas F agar. After incubation for $24 \mathrm{~h}$ at $30^{\circ} \mathrm{C}$, the number of CFU was determined.

MS.

All MALDI-TOF mass spectra were obtained on a Voyager Workstation MALDI-TOF mass spectrometer (Applied Biosystems, Foster City, CA, U.S.A.) in linear, positive mode. The sample solutions were prepared in water containing $0.1 \%$ triflouroacetic acid (TFA). All samples were prepared by a dried droplet method in which the analyte (intact protein or peptide mixture) was mixed with a threefold volume of matrix solution (saturated solution of $\alpha$-cyano-4-hydroxycinnamic acid in $100 \%$ acetonitrile with $0.1 \%$ TFA [vol $/ \mathrm{vol}]$ ), and then the mixture was deposited on a stainless target plate.

\section{ACKNOWLEDGMENTS}

This work was supported, in part, by Technology of Japan and the Program for Promotion of Basic and Applied Research for Innovations in Biooriented Industry and Grant-in-Aid for Scientific Research (B) (25292067) from the Ministry of Education, Culture, Sports, Science. We thank $\mathrm{H}$ Morii for excellent technical support.

\section{LITERATURE CITED}

Boller, T., and Felix, G. 2009. A renaissance of elicitors: perception of microbe-associated molecular patterns and danger signals by patternrecognition receptors. Annu. Rev. Plant Biol. 60:379-406.

Che, F. S., Iwano, M., Tanaka, N., Takayama, S., Minami, E., Shibuya, N., Kadota, I., and Isogai, A. 1999. Biochemical and morphological features of rice cell death induced by Pseudomonas avenae. Plant Cell Physiol. 40:1036-1045.

Che, F. S., Nakajima, Y., Tanaka, N., Iwano, M., Yoshida, T., Takayama, S., Kadota, I., and Isogai, A. 2000. Flagellin from an incompatible 
strain of Pseudomonas avenae induces a resistance response in cultured rice cells. J. Biol. Chem. 275:32347-32356.

Coll, N. S., Epple, P., and Dangl, J. L. 2011. Programmed cell death in the plant immune system. Cell Death Differ. 18:1247-1256.

Felix, G., Duran, J. D., Volko, S., and Boller, T. 1999. Plants have a sensitive perception system for the most conserved domain of bacterial flagellin. Plant J. 18:265-276.

Fujiwara, S., Tanaka, N., Kaneda, T., Takayama, S., Isogai, A., and Che, F. S. 2004. Rice cDNA microarray-based gene expression profiling of the response to flagellin perception in cultured rice cells. Mol. PlantMicrobe Interact. 17:986-998.

Gómez-Gómez, L., and Boller, T. 2000. FLS2: An LRR receptor-like kinase involved in the perception of the bacterial elicitor flagellin in Arabidopsis. Mol. Cell 5:1003-1011.

Heffron, S. E., Moeller, R., and Jurnak, F. 2006. Solving the structure of Escherichia coli elongation factor Tu using a twinned data set. Acta Crystallogr. D Biol. Crystallogr. 62:433-438.

Hirai, H., Takai, R., Iwano, M., Nakai, M., Kondo, M., Takayama, S., Isogai, A., and Che, F. S. 2011. Glycosylation regulates specific induction of rice immune responses by Acidovorax avenae flagellin. J. Biol. Chem. 286:25519-25530.

Iwano, M., Che, F. S., Goto, K., Tanaka, N., Takayama, S., and Isogai, A. 2002. Electron microscopy analysis of the $\mathrm{H}_{2} \mathrm{O}_{2}$ accumulation preceding hypersensitive cell death induced by an incompatible strain of Pseudomonas avenae in cultured rice cells. Mol. Plant Pathol. 3:1-8.

Jonák, J. 2007. Bacterial elongation factors EF-Tu, their mutants, chimeric forms, and domains: Isolation and purification. J. Chromatogr. B Analyt. Technol. Biomed. Life Sci. 849:141-153.

Jones, J. D., and Dangl, J. L. 2006. The plant immune system. Nature 444:323-329.

Kadota, I., Mizuno, A., and Nishiyama, K. 1996. Detection of a protein specific to the strain of Pseudomonas avenae Manns 1909 pathogenic to rice. Ann. Phytopathol. Soc. Jpn. 62:425-428.

Kaku, H., Nishizawa, Y., Ishii-Minami, N., Akimoto-Tomiyama, C., Dohmae, N., Takio, K., Minami, E., and Shibuya, N. 2006. Plant cells recognize chitin fragments for defense signaling through a plasma membrane receptor. Proc. Natl. Acad. Sci. U.S.A. 103:11086-11091.

Kaneda, T., Taga, Y., Takai, R., Iwano, M., Matsui, H., Takayama, S., Isogai, A., and Che, F. S. 2009. The transcription factor OsNAC4 is a key positive regulator of plant hypersensitive cell death. EMBO (Eur. Mol. Biol. Organ.) J. 28:926-936

Klarzynski, O., Plesse, B., Joubert, J. M., Yvin, J. C., Kopp, M., Kloareg, B., and Fritig, B. 2000. Linear beta-1,3 glucans are elicitors of defense responses in tobacco. Plant Physiol. 124:1027-1038.

Kunze, G., Zipfel, C., Robatzek, S., Niehaus, K., Boller, T., and Felix, G. 2004. The $\mathrm{N}$ terminus of bacterial elongation factor $\mathrm{Tu}$ elicits innate immunity in Arabidopsis plants. Plant Cell 16:3496-3507.

Lacombe, S., Rougon-Cardoso, A., Sherwood, E., Peeters, N., Dahlbeck, D., van Esse, H. P., Smoker, M., Rallapalli, G., Thomma, B. P., Staskawicz, B., Jones, J. D., and Zipfel, C. 2010. Interfamily transfer of a plant pattern-recognition receptor confers broad-spectrum bacterial resistance. Nat. Biotechnol. 28:365-369.

Laquitaine, L., Gomès, E., François, J., Marchive, C., Pascal, S., Hamdi, S., Atanassova, R., Delrot, S., and Coutos-Thévenot, P. 2006. Molecular basis of ergosterol-induced protection of grape against Botrytis cinerea: Induction of type I LTP promoter activity, WRKY, and stilbene synthase gene expression. Mol. Plant-Microbe Interact. 19:1103-1112.

Luna, E., Pastor, V., Robert, J., Flors, V., Mauch-Mani, B., and Ton, J. 2011. Callose deposition: A multifaceted plant defense response. Mol. Plant-Microbe Interact. 24:183-193.

Monaghan, J., and Zipfel, C. 2012. Plant pattern recognition receptor complexes at the plasma membrane. Curr. Opin. Plant Biol. 15:349-357.

Samatey, F. A., Imada, K., Nagashima, S., Vonderviszt, F., Kumasaka, T., Yamamoto, M., and Namba, K. 2001. Structure of the bacterial flagellar protofilament and implications for a switch for supercoiling. Nature 410:331-337.

Schwacke, R., and Hager, A. 1992. Fungal elicitors induce a transient release of active oxygen species from cultured spruce cells that is dependent on $\mathrm{Ca}^{2+}$ and protein-kinase activity. Planta 187:136-141.

Schwessinger, B., Roux, M., Kadota, Y., Ntoukakis, V., Sklenar, J., Jones, A., and Zipfel, C. 2011. Phosphorylation-dependent differential regulation of plant growth, cell death, and innate immunity by the regulatory receptor-like kinase BAK1. PLoS Genet. 7:e1002046.

Shiu, S. H., Karlowski, W. M., Pan, R., Tzeng, Y. H., Mayer, K. F., and Li, W. H. 2004. Comparative analysis of the receptor-like kinase family in Arabidopsis and rice. Plant Cell 16:1220-1234.

Silipo, A., Molinaro, A., Sturiale, L., Dow, J. M., Erbs, G., Lanzetta, R., Newman, M. A., and Parrilli, M. 2005. The elicitation of plant innate immunity by lipooligosaccharide of Xanthomonas campestris. J. Biol. Chem. 280:33660-33668.

Takai, R., Kaneda, T., Isogai, A., Takayama, S., and Che, F. S. 2007. A new method of defense response analysis using a transient expression system in rice protoplasts. Biosci. Biotechnol. Biochem. 71:590-593.

Takai, R., Isogai, A., Takayama, S., and Che, F. S. 2008. Analysis of flagellin perception mediated by flg22 receptor OsFLS2 in rice. Mol. Plant-Microbe Interact. 21:1635-1642.

Tanaka, N., Nakajima, Y., Kaneda, T., Takayama, S., Che, F. S., and Isogai, A. 2001. DNA laddering during hypersensitive cell death in cultured rice cell induced by an incompatible strains of Pseudomonas avenae. Plant Biotechnol. 18:295-299.

Tanaka, N., Che, F. S., Watanabe, N., Fujiwara, S., Takayama, S., and Isogai, A. 2003. Flagellin from an incompatible strain of Acidovorax avenae mediates $\mathrm{H}_{2} \mathrm{O}_{2}$ generation accompanying hypersensitive cell death and expression of PAL, Cht-1, and PBZ1, but not of Lox in rice. Mol. Plant-Microbe Interact. 16:422-428.

Yonekura, K., Maki-Yonekura, S., and Namba, K. 2003. Complete atomic model of the bacterial flagellar filament by electron cryomicroscopy Nature 424:643-650.

Zipfel, C., Kunze, G., Chinchilla, D., Caniard, A., Jones, J. D., Boller, T. and Felix, G. 2006. Perception of the bacterial PAMP EF-Tu by the receptor EFR restricts Agrobacterium-mediated transformation. Cell 125:749-760 